\title{
Most northern Oriental distribution of Zethus Fabricius (Hymenoptera,Vespidae, Eumeninae), with a new species from China
}

\author{
Jiang-Li Tan', James M Carpenter², Cornelis van Achterberg' \\ I Shaanxi Key Laboratory for Animal Conservation/Key Laboratory of Resource Biology and Biotechnology in \\ Western China, Ministry of Education, College of Life Sciences, Northwest University, Xi'an, China 2 Division \\ of Invertebrate Zoology, American Museum of Natural History, New York, NY, USA \\ Corresponding author: Jiang-LiTan (tanjl@nwu.edu.cn) \\ Academic editor: $M . O h l \mid$ Received 22 December 2017 | Accepted 19 January 2018 | Published 26 February 2018 \\ http://zoobank.org/27CAA30D-E514-4ECE-8095-010F6141E8B0 \\ Citation: Tan J-L, Carpenter JM, van Achterberg C (2018) Most northern Oriental distribution of Zethus Fabricius \\ (Hymenoptera, Vespidae, Eumeninae), with a new species from China. Journal of Hymenoptera Research 62: 1-13. \\ https://doi.org/10.3897/jhr.62.23196
}

\begin{abstract}
The distribution of Zethus Fabicius, 1804, in the Oriental and Palaearctic regions is discussed, with special reference to the northeastern Oriental species. A newly discovered species, Z. velamellatus Tan, sp. n. from China (Zhejiang), is described and illustrated. The first key to species of Zethus Fabricius from China is presented. Zethus nigerrimus Gusenleitner, 2001 is recorded for the first time from China and redescribed.
\end{abstract}

\section{Keywords}

Zethus, China, key, new record, new species

\section{Introduction}

Zethus Fabricius, 1804, is the largest eumenine genus with 272 valid species of which the majority (230 spp.) occurs in the New World (Carpenter 2011, Lopes et al. 2015, 2017, Cooper 2016, Nguyen and Carpenter 2016, Nguyen and Xu 2017, Selis 2017, Yeh and $\mathrm{Lu}$ 2017). The genus is characterized by having propodeum with orifice elongate, acutely pointed dorsally, propodeal valvula elongate and quadrate, separate from propodeal lamella; labial palp four-segmented; mid-tibia usually with two spurs (Bohart and Stange 1965, Nguyen and Carpenter 2016, Tan et al. 2018, submitted).

Copyright Jiang-LiTan et al. This is an open access article distributed under the terms of the Creative Commons Attribution License (CC BY 4.0), which permits unrestricted use, distribution, and reproduction in any medium, provided the original author and source are credited 
Although they are widespread in the tropics, with 25 species occurring in the Oriental Region (Nguyen and Carpenter 2016, Nguyen and Xu 2017, Yeh and Lu 2017), only few species and specimens are known from China. Lee (1985) was the first to record a Zethus sp. from China: $Z$. dolosus Bingham, 1897. Unfortunately, the record by Lee (1985) was overlooked by Zhou et al. (2011) and Nguyen and Xu (2017). Up to the present, there are only four species recorded from China (Lee 1985, Nguyen and Xu 2017, Yeh and Lu 2017, Tan et al. 2018, submitted). In this paper, two additional species, $Z$. velamellatus Tan, sp. n. and $Z$. nigerrimus Gusenleitner, 2001, rec. n., are added to the Chinese fauna. A key to species of the genus Zethus from China is included.

\section{Material and methods}

Specimens were collected by hand net. The studied specimens are deposited in the Hymenoptera Collection of the College of Life Sciences, Northwest University, Xi'an (NWUX). Morphological terminology follows Yeh and Lu (2017) and Nguyen and Xu (2017). Nomenclature of mesopleural sulci and sutures is shown in Figure 1. Length of body is measured from anterior margin of the head to the apex of the second metasomal tergum; length of first metasomal tergum is measured from the posterior margin of the tendon to the apex of the tergum medially, its height is the maximum height in lateral view. Observations and descriptions were made with an Olympus SZX11 stereomicroscope and fluorescent lamps. Photographic images were made with a Keyence VHX-5000 digital microscope and Photoshop CS 6 was used to make the plates.

Abbreviations: approx., approximately; id., idem; F, antennal flagellomere; S, metasomal sternum; T, metasomal tergum; ecc, epicnemial carina; eps, epipleural sulcus; ess, episternal sulcus; mps, mesopleural suture.

Table I. List of Zethus spp. recorded from Oriental and Palaearctic fauna.

\begin{tabular}{l|l}
\multicolumn{1}{c|}{ Oriental species } & \multicolumn{1}{c}{ Distribution } \\
\hline Zethus albopilosus Giordani Soika, 1995 & India \\
\hline Zethus angulatus Nguyen \& Carpenter, 2016 & Vietnam \\
\hline Zethus bakeri Giordani Soika, 1995 & Singapore \\
\hline Zethus celebensis Giordani Soika, 1960 & Indonesia \\
\hline Zethus ceylonicus de Saussure, 1867 & India, Sri Lanka \\
\hline Zethus dolosus Bingham, 1897 & China (Guangdong), Bhutan, India, \\
\hline Zethus fulgens Gusenleitner, 2007 & Myanmar, Thailand, Vietnam \\
\hline Zethus improcerus Giordani Soika, 1995 & Malaysia \\
\hline Zethus indicus Giordani Soika, 1960 & Malaysia \\
\hline Zethus luzonensis Giordani Soika, 1941 & India (Sikkim) \\
\hline Zethus malabaricus Giordani Soika, 1995 & Philippines \\
\hline Zethus malayanus Gusenleitner, 2010 & India \\
\hline
\end{tabular}




\begin{tabular}{l|l}
\hline \multicolumn{1}{c|}{ Oriental species } & \multicolumn{1}{c}{ Distribution } \\
\hline Zethus mandibularis Giordani Soika, 1995 & Indonesia \\
\hline Zethus nanlingensis Nguyen \& Xu, 2017 & China (Guangdong) \\
\hline Zethus nigerrimus Gusenleitner, 2001 & China (Jiangxi), Vietnam, Laos, Malaysia \\
\hline Zethus planiclypeus Gusenleitner, 1988 & Thailand \\
\hline Zethus propodeus Nguyen \& Carpenter, 2016 & Vietnam \\
\hline Zethus puehringeri Gusenleitner \& Gusenleitner, 2013 & Laos \\
\hline Zethus quadridentata Cameron, 1902 & Borneo \\
\hline Zethus soikai Selis, 2017 & Philippines \\
\hline Zethus tansoneus Nguyen \& Carpenter, 2016 & Vietnam \\
\hline Zethus trimaculatus Cameron, 1904 & India, Laos, Vietnam \\
\hline Zethus tumidus Nguyen \& Carpenter, 2016 & Vietnam \\
\hline Zethus varipunctatus Cameron, 1902 & Malaysia \\
\hline Zehtus velamellatus Tan, sp. n. & China (Zhejiang) \\
\hline Palaearctic species & \\
\hline Zethus asiaticus Gusenleitner, 2011 & Kyrgyzstan \\
\hline Zethus favillaceus Walker, 1871 & Saudi Arabia, Djibouti, Sudan, Kenya, \\
\hline
\end{tabular}

\section{Key to species of the genus Zethus from China}

1 First metasomal segment short and stout: $2.0-2.2 \times$ as long as its maximum width in dorsal view and approx. $2.5 \times$ as long as high in lateral view ......... 2

- $\quad$ First metasomal segment long and slender: $2.5-3.5 \times$ as long as its maximum width in dorsal view and $3.3-6.0 \times$ as long as high in lateral view..............4

2 Propodeal lamella almost invisible as the submarginal carina is not produced above propodeal valvulae; mesopleuron reticulate-rugose; first metasomal tergum punctate; clypeus of $q$ punctate-reticulate and depressed space between apical teeth without median ridge; second tergum with apical yellow band. China (Zhejiang) ....................................... Z. velamellatus Tan, sp. n.

- $\quad$ Propodeal lamella well-developed as the submarginal carina is produced into a distinct lamella above propodeal valvulae; mesopleuron sparsely punctate; first metasomal tergum reticulate-rugose; clypeus of $q$ punctate and depressed space between apical teeth with a median ridge; second tergum completely black

3 Leg yellowish brown; clypeus of $q$ tri-dentate, clypeus of $\hat{\jmath}$ with apical notch $1 / 5$ as wide as clypeus; mandible of $\widehat{T}$ with basal tooth forming a rectangular plate and separated from middle tooth by a broad notch. China (Taiwan) ....

Z. taiwanus Yeh \& Lu, 2017

- $\quad$ Leg black; clypeus of $q$ minutely bi-dentate, clypeus of $\widehat{\gamma}$ with apical notch $1 / 6$ as wide as clypeus; mandible of $\hat{\sigma}$ with two small basal teeth, similarly shaped and not separated by a broad notch. China (new record; Jiangxi); Laos; Malaysia; Vietnam 
4 First metasomal tergum long and slender, approx. 3.5x as long as wide, densely and coarsely punctate, and with median carina; propodeum shiny and with lateral carinae. China (Guangdong); Bhutan; India; Myanmar; Thailand; Vietnam.

- $\quad$ First metasomal tergum relatively short and wider, approx. $2.5 \times$ as long as wide, finely punctate, and without median carina; propodeum dull and without lateral carinae.

First metasomal tergum in dorsal view nearly parallel-sided; second metasomal segment relatively long, $1.2 \times$ as long as wide; China (Guangdong); Malaysia; Vietnam

Z. malayanus Gusenleitner, 2010

- $\quad$ First metasomal tergum in dorsal view gradually widening from base to basal one-sixth of tergum, then gradually narrowed apically; second metasomal segment relatively short, $1.4 \times$ as long as wide; China (Guangdong)

Z. nanlingensis Nguyen \& Xu, 2017

\section{Taxonomy}

Zethus nigerrimus Gusenleitner, 2001, rec. n.

Figs 2-13

Zethus nigerrimus Gusenleitner, 2001: 659 (ㅇ, N. Vietnam, Naturhistorisches Museum Wien); 2017: 101; 2012: 1050; Gusenleitner and Gusenleitner 2013: 138; Yeh and Lu 2017: 536.

Material examined. 19 (NWUX): "CHINA: Jiangxi, Fuzhou, Zixi, 7.vi.2010, $\mathrm{N} 27.70^{\circ}, \mathrm{E} 117.05^{\circ}$, Meijuan Lou”.

Diagnosis. Body about $13.1 \mathrm{~mm}$, almost entirely black, except a pair of yellow spots near dorso-inner margin of antennal sockets, and a pair of transverse yellow lateral spots on apical margin of TI (Figs 2, 3, 9). Clypeus of $q$ densely and shallowly foveate, minutely bi-dentate apically, depressed space between teeth with a median ridge (Fig. 10). Anterior half of mesoscutum strongly punctate-rugose, posterior half of mesoscutum, mesoscutellum and metanotum sparsely punctate with distance between punctures much longer than diameter of puncture. Epicnemial carina (Fig. 1, ecc) strong and raised, bordered posteriorly by narrow sulcus; episternal sulcus (Fig. 1, ess) wide, distinctly crenulate and depressed (Fig. 3), epipleural sulcus (Fig. 1 eps) indistinct; mesopleura (episternum) sparsely punctate below episternal and epipleural sulci, epicnemium and posterior part of episternum coriaceous (Fig. 3). Propodeum coriaceous with strong striae laterally; posterior depression very shallow, almost flat and finely transversely striate, submedian carina indiscernible; propodeal lamella well developed and protruding upward (Figs 6, 7). TI short, approx. $2.2 \times$ as long as wide in dorsal view and reticulate-rugose (Fig. 6); anterior half of SI reticulate-rugose and foveolate, posterior half densely transversely striate (Fig. 8). TII approx. 1.4x as long as wide in dorsal view, sparsely micro-punctate (Figs 12, 13); TII, TIII and SII with 


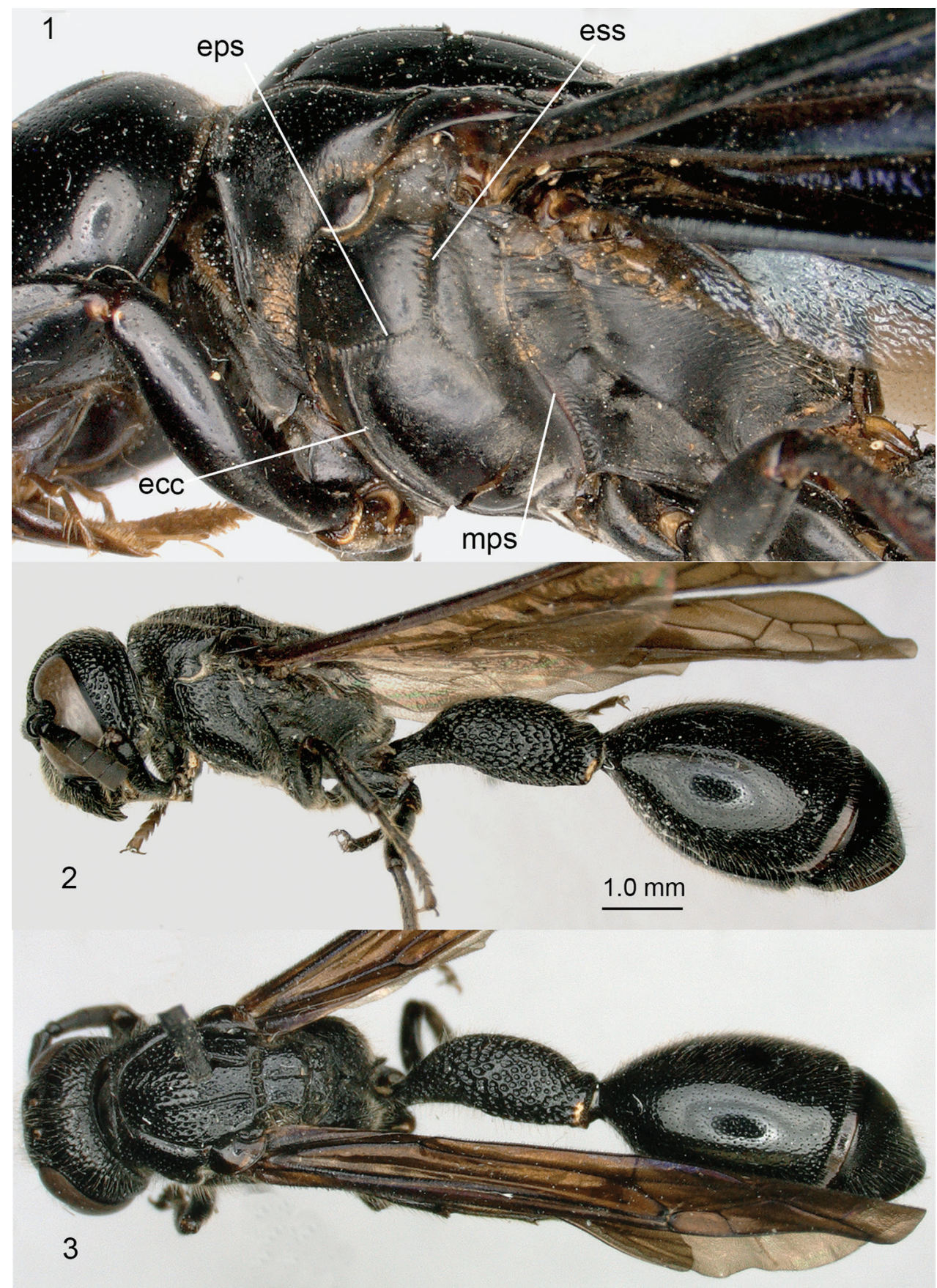

Figures I-3. I Zethus coeruleopennis (Fabricius), mesosoma, lateral aspect 2-3 Z. nigerrimus Gusenleitner, +2 Habitus, lateral aspect $\mathbf{3}$ id., dorsal aspect. Abbreviations: ecc = epicnemial carina; eps = epipleural sulcus; ess = episternal sulcus; $\mathrm{mps}=$ mesopleural suture . 


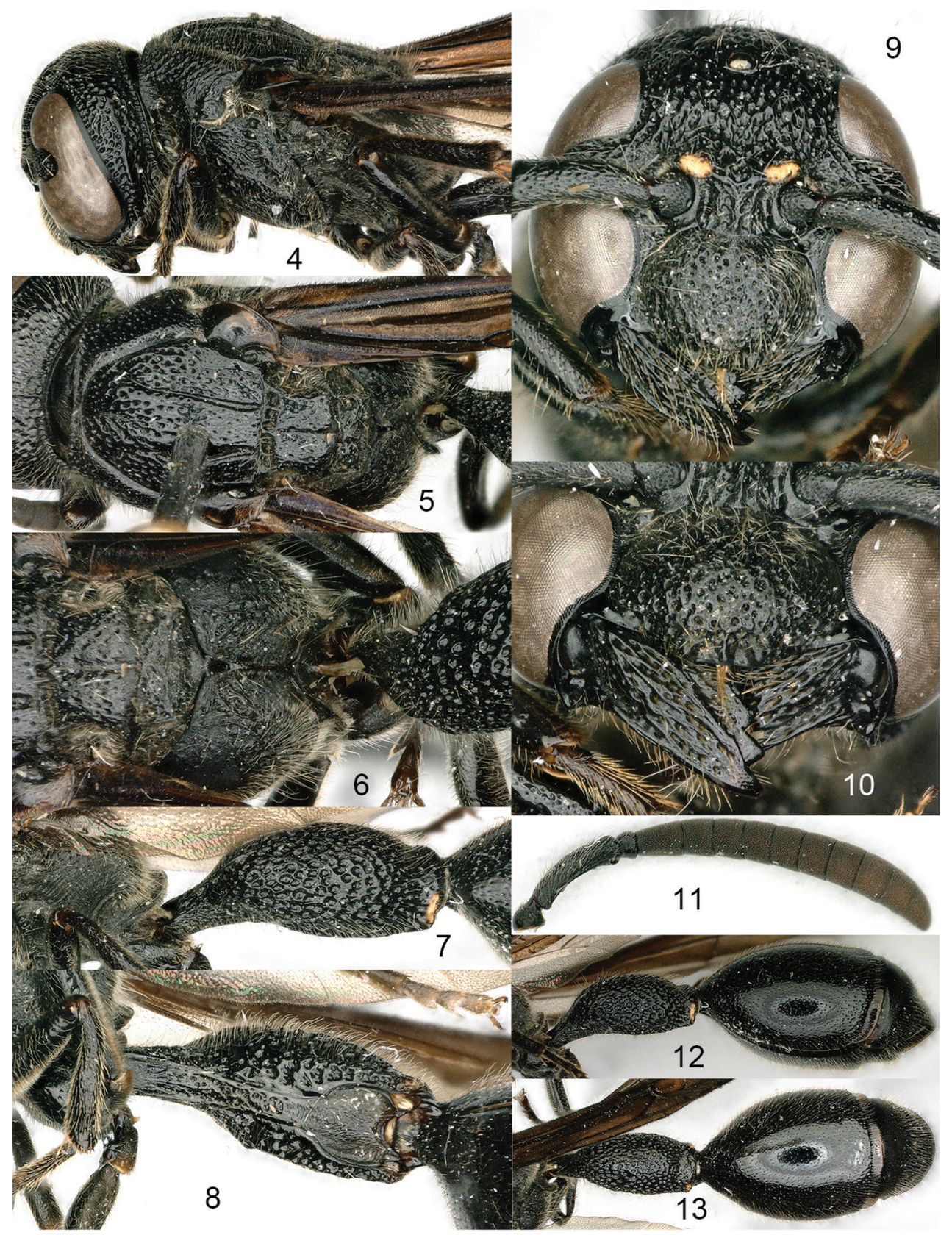

Figures 4-13. Zethus nigerrimus Gusenleitner, $\circ$. 4 Head and mesosoma, lateral aspect 5 mesosoma dorsal aspect $\mathbf{6}$ propodeum, dorsal aspect $\mathbf{7}$ propodeum and TI, lateral aspect $\mathbf{8}$ SI, ventral aspect $\mathbf{9}$ head, anterior aspect $\mathbf{I} \mathbf{0}$ clypeus, anterior aspect $\mathbf{I} \mathbf{I}$ antenna $\mathbf{I} \mathbf{2}$ metasoma, lateral aspect $\mathbf{I} \mathbf{3}$ metasoma, dorsal aspect.

well-developed apical lamella, flat (about $0.25 \mathrm{~mm}, 0.4 \mathrm{~mm}$ and $0.17 \mathrm{~mm}$ long respectively); SII in lateral view smoothly curved from base to apical margin (Fig. 12).

Distribution. China (Jiangxi); Vietnam, Laos; Malaysia. It is a new record for China. 


\section{Zethus velamellatus Tan, sp. $\mathbf{n}$.}

http://zoobank.org/DBA926D0-5F9C-44CC-B9C1-C39C4E8BA572

Figs $14-24$

Material examined. Holotype, $q$ (NWUX): "CHINA: Zhejiang, Hangzhou, Lin'an, Qingliangfeng, Shunxi, N30.06 E118.94², 23.viii.2013, Jiangli Tan”.

Diagnosis. Clypeus of $q$ punctate-reticulate and depressed space between apical teeth without median ridge; mesopleuron reticulate-rugose; propodeal lamella almost invisible as the submarginal carina is not produced above propodeal valvulae; T1 unevenly punctate and approx. twice as long as its maximum width in dorsal view and approx. $2.4 \times$ as long as high in lateral view; SI densely striate and sparsely punctate; TI with apical yellow band.

Description. Length of body $13.0 \mathrm{~mm}$; fore wing length $11 \mathrm{~mm}$; width of mesonotum (including tegulae) $3.1 \mathrm{~mm}$.

Head. Head transversely oblong, approx. $1.3 \times$ wider than high in anterior view (Fig. 20), about $2.2 \times$ wider than long in dorsal view, coarsely punctate-reticulate and with long setae. Temple contracted behind eyes, approx. $1.2 \times$ wider than eye in dorsal view. Occipital carina developed, with crenulae in front of it. Clypeus gently convex, slightly less than twice as wide as long, emarginated at basal margin; apex minutely bidentate, depressed space between both teeth without median ridge (Fig. 21); clypeus punctate-reticulate with dense yellowish brown long setae (more than three times ocellar diameter); width of apical depression about a quarter width of clypeus. Mandible with four teeth, coarsely punctate-rugose, third and fourth teeth truncated. Antennal scape punctate, $2.7 \times$ as long as its maximum width; FI $1.9 \times$ as long as its maximum width, FII as long as wide, FIII-IX wider than long, FX bullet-shaped, as long as its basal width (Fig. 22).

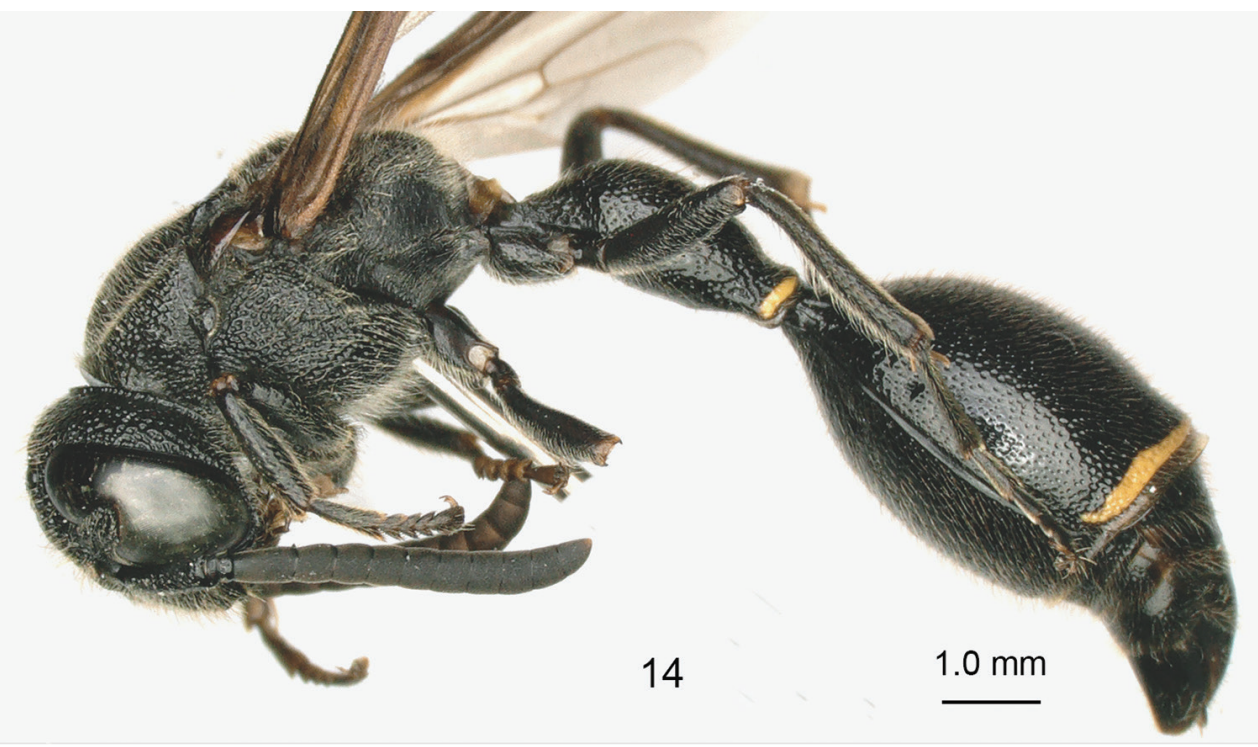

Figure 14. Zethus velamellatus Tan, sp. n., holotype,, , habitus, lateral aspect. 


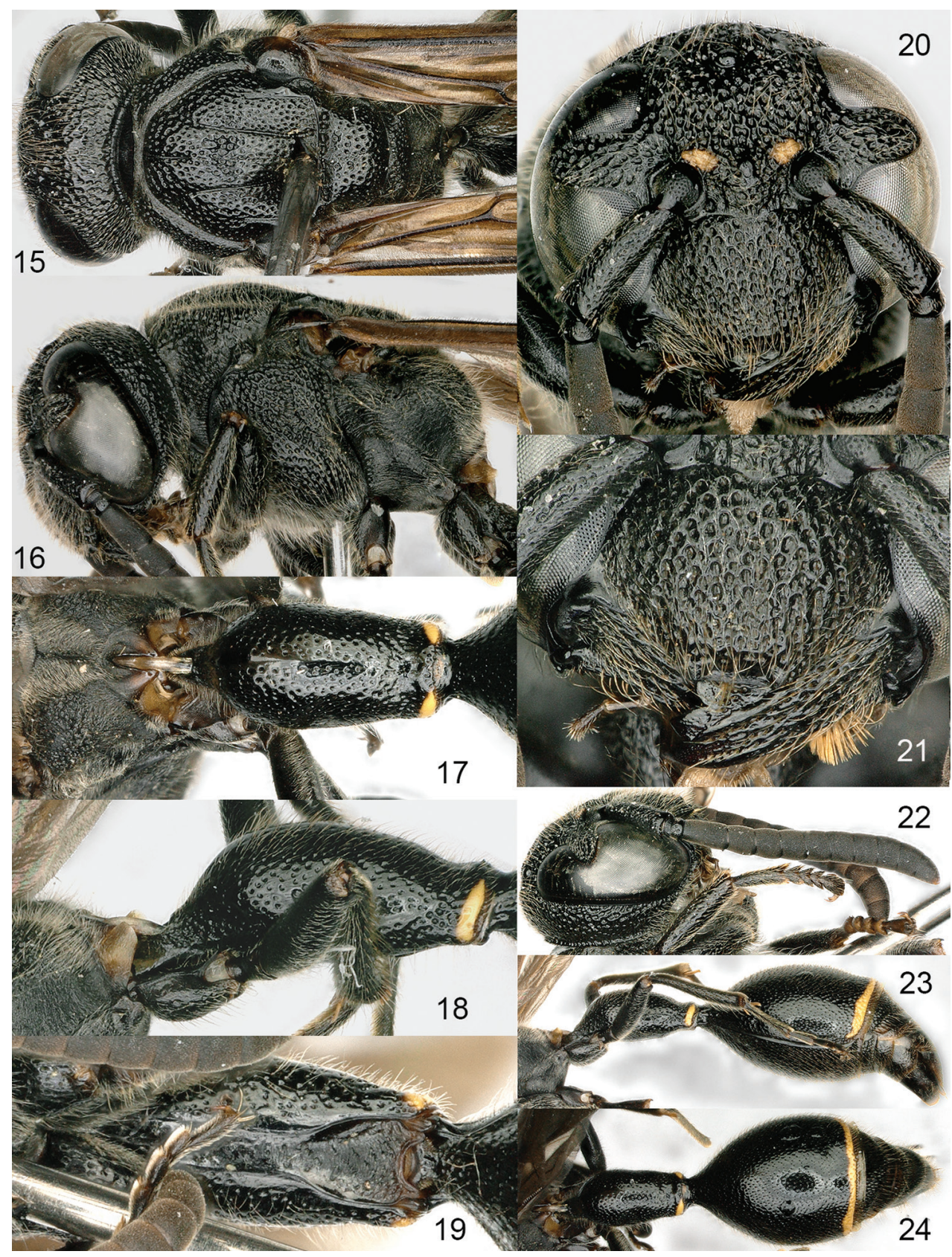

Figures 15-24. Zethus velamellatus Tan, sp. n., holotype, + . I 5 Head and mesosoma, dorsal aspect $\mathbf{1 6}$ head and mesosoma, lateral aspect $\mathbf{I} \mathbf{7}$ propodeum and TI, dorsal aspect $\mathbf{1} \mathbf{8}$ propodeum and TI, lateral aspect $\mathbf{1 9}$ SI, ventral aspect $\mathbf{2 0}$ head, anterior aspect $\mathbf{2} \mathbf{I}$ clypeus, anterior aspect $\mathbf{2 2}$ antenna $\mathbf{2 3}$ metasoma, lateral aspect $\mathbf{2 4}$ metasoma, dorsal aspect. 
Mesosoma. Pronotum reticulate-punctate dorsally with ventro-lateral area punctate-rugose (Fig. 15-16). Mesoscutum coarsely rugose-punctate to densely punctate (Fig. 15); mesoscutellum and metanotum coarsely punctate with distance between punctures less than diameter of puncture. Epicnemial carina distinct, bordered posteriorly by a narrow sulcus; episternal sulcus indistinctly developed as a crenulate depression, epipleural suture indistinct; mesopleuron (episternum) coarsely punctaterugose (Fig. 16), below pleural and epipleural sulci densely punctate-rugose with epicnemium and posterior part of episternum coriaceous (Fig.16). Propodeum coriaceous-aciculate laterally and without lateral carina (Fig. 17), coriaceous-reticulate postero-laterally and oblique punctate-rugose along each side of median carina and with dense setae (Fig. 17); submarginal carina not produced into a lamella resulting in absence of propodeal lamella above propodeal valvula (Fig. 17).

Metasoma. TI short, about twice as long as wide in dorsal view, gradually widened from base to basal one third, then slightly narrowed toward apex, with maximum width $3.1 \times$ its basal width (Fig. 17); in lateral view smoothly curved between basal stem and apical part; strongly convex dorsally, about $2.4 \times$ as long as high (Fig. 18); TI unevenly punctate; SI densely striate and sparsely punctate (Fig. 19). TII sparsely punctate with rather short petiole basally, about $1.4 \times$ as long as wide in dorsal view (Figs 23, 24); SII in lateral view smoothly curved from base to apical margin (Fig. 23); TII and SII with raised apical lamella of approx. $0.2 \mathrm{~mm}$ and $0.1 \mathrm{~mm}$ long, respectively, apical lamella of TIII flat and approx. $0.25 \mathrm{~mm}$ long.

Colour (Figs 14-19). Body black, except a yellow spot near dorso-inner margin of antennal socket, a pair of transverse yellow lateral spots on apical margin of TI, TII with a narrow yellow subapical band and propodeal valvula yellowish brown. Wings yellowish brown tinged.

Remarks. Zethus velamellatus sp. n. fits well into the trimaculatus-group (Giordani Soika 1958, Yeh and Lu 2017) in sharing the main character of a short and stout first metasomal segment. The new species is easily to separate because of the missing submarginal lamella of the propodeum, the punctate sculpture of SI and smoothly curved profile of SII in lateral view.

Distribution. China (Zhejiang).

Etymology. This species is named "velamellatus ("ve" is Latin for "without") because the propodeal lamella is invisible in this species.

\section{Discussion of Oriental and Palaearctic distribution of Zethus Fabricius}

Zethus Fabricius, 1804, is the most speciose genus of the Vespidae. It consists of 272 valid species, mainly occurring in the pantropical area with most species in the Neotropical region (230 species); the numbers are much lower for the other regions Afrotropical (15), Oriental (26), and Palaearctic (2) (Giordani Soika 1940, Bohart and Stange 1965, Gusenleitner 2011, Carpenter et al. 2010, Carpenter and Madl 2011, 


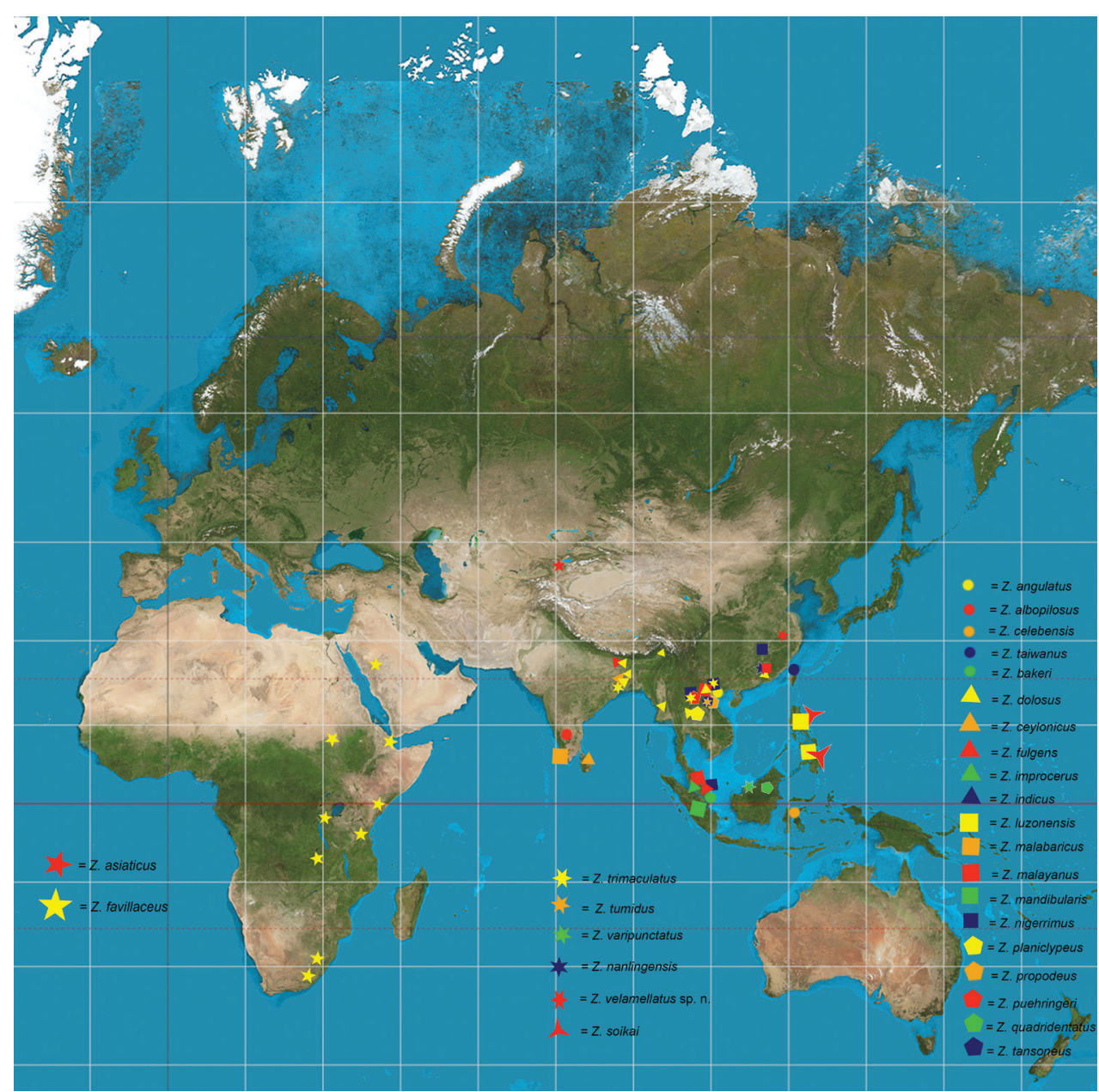

Figure 25. Zoogeographical map illustrating Zethus spp. recorded from Oriental and Palaearctic regions; $Z$. favillaceus is included as borderline species. Map from: http://blogs.discovermagazine.com.

Nugroho et al. 2012, Nidup et al. 2016, Nguyen and Carpenter 2016, Carpenter, unpublished). In addition, Bohart and Stange (1965) reported one undescribed species from Australia. Compared with its Oriental congeners, $Z$. velamellatus is the most northern $\left(30^{\circ} \mathrm{N}\right)$ species known so far. The type locality (Fig. 25) lies within the boundaries of the Palaearctic-Oriental transitional zone as defined for mammals (between $33^{\circ} \mathrm{N}$ and $28^{\circ} \mathrm{N}$; Hoffmann 2001).

A widespread but sporadic distribution may suggest a relict group (Tan et al. 2010). Hermes et al. (2014) recovered Zethini sensu lato as the sister-lineage to the remaining Eumeninae. The fossil and phylogeny of the genus is still unclear (Bohart and Stange 1965). The genus has been divided into four subgenera: Zethoides Fox and Zethusculus de Saussure, are restricted to the Western Hemisphere, Madecazethus Giordani Soika is endemic in Madagascar, but Zethus Fabricius s. str. is pantropical (Bohart and Stange 
1965, Giordani Soika 1979). This distribution pattern fits well with "classic Indian Ocean (Gondwanic)" pattern (de Jong and van Achterberg 2007; especially the example of the genus Celaenorrhinus (Lepidoptera)). The research on Cretaceous fossil Vespidae reveals two basal groups (Priorvespinae and Euparagiinae) indicating that the time of subfamily-level division of Vespidae could be traced back to about 120-65 Ma (Carpenter and Rasnitsyn 1990). The connection between Africa and South America was severed during Late Cretaceous, at least $80 \mathrm{Ma}$ (Hallam 1994). The minimum age of the Eumeninae is estimated to be approx. $90 \mathrm{Ma}$ (Perrard et al. 2017) and the origin of the genus Zethus could be estimated between 90-80 Ma, allowing for the Gondwanic distribution pattern.

\section{Acknowledgements}

We wish to thank Dr Maoling Sheng (Shenyang) for his kind help with collecting specimens. The paper was considerably improved by the critical remarks of both reviewers (Lien Thi Phuong Nguyen and Girish P. Kumar) and the editor (Michael Ohl). The research was supported jointly by the National Natural Science Foundation of China (NSFC, No. 31201732, 31572300), the Research Fund for the Doctoral Program of Higher Education of China (No. 20116101120001), the Opening Foundation of Shaanxi Key Laboratory for Animal Conservation, Northwest University, China, and American Museum of Natural History collection study grant (No. P305062).

\section{References}

Bohart RM, Stange LA (1965) A revision of the genus Zethus Fabricius in the Western Hemisphere. University of California Publications in Entomology 40: 1-208.

Carpenter JM (2011) A new species of Zethus (Hymenoptera, Vespidae, Eumeninae). Linzer biologische Beiträge 43(2): 1123-1126.

Carpenter JM, Gusenleitner J, Madl M (2010) A Catalogue of the Eumeninae (Hymenoptera: Vespidae) of the Ethiopian Region excluding Malagasy Subregion. Part II: Genera Delta de Saussure 1885 to Zethus Fabricius 1804 and species Incertae Sedis. Linzer biologische Beiträge 42(1): 95-315.

Carpenter JM, Madl M (2009) A Catalogue of the Vespidae of the Malagasy Subregion (Insecta, Hymenoptera). Linzer biologische Beiträge 41(2): 1871-1935.

Cooper M (2016) A new species and new records of Zethus Fabricius in the pallidus-group (Hymenoptera: Vespidae, Eumeninae). Entomologist's Monthly Magazine 152: 207-210. de Jong R, van Achterberg C (2007) Global disjunctions and flying insects. In: Renema W (Ed.) Biogeography, Time and Place. Distributions, Barriers and Islands. Topics in Geobiology 29, 6-44. https://doi.org/10.1007/978-1-4020-6374-9_1

Fabricius JC (1804) Systema Piezatorum, secundum: Ordines, Genera, Species adiectis Synonymis, locis, observationibus, descriptionibus. Carolum Reichard, Brunsvigae. 
Giordani Soika A (1940) Le specie etiopiche e malagasse del genere Zethus F. (Hym. Vespidae). Memorie della Società Entomologica Italiana 19: 129-139.

Giordani Soika A (1958) Notule vespidologiche VIII., Contributo alla conoscenza degli Zethus orientali. Bollettino del Museo Civico di Storia Naturale di Venezia 11: 75-80.

Giordani Soika A (1979) Revisione delle specie Ethiopiche e Malgasce della sottofamiglia Discoelinae (Hym.). Bollettino del Museo Civico di Storia Naturale di Venezia 30: 19-65.

Gusenleitner J (2001) Beitrag zur Kenntnis von Faltenwespen der orientalischen Region (Hymenoptera, Vespidae, Eumenidae). Linzer biologische Beiträge 33: 655-662.

Gusenleitner J (2007) Bemerkenswerte Faltenwespen-Funde aus der orientalischen Region. Teil 3 (Hymenoptera: Polistinae, Eumenidae). Linzer biologische Beiträge 39: 97-104.

Gusenleitner J (2011) Eine Aufsammlung von Faltenwespen aus Laos im Biologiezentrum Linz (Hymenoptera: Vespidae: Vespinae, Stenogastrinae, Polistinae, Eumeninae). Linzer biologische Beiträge 43: 1351-1368.

Gusenleitner J (2012) Bemerkenswerte Faltenwespen-Funde aus der orientalischen Region Teil 6 (Hymenoptera: Vespidae, Eumeninae). Linzer biologische Beiträge 44: 1045-1052.

Gusenleitner J, Gusenleitner F (2013) Eine neue Gattung und zwei neue Faltenwespen aus der orientalischen Region (Hymenoptera, Vespidae, Eumeninae). Linzer biologische Beiträge 45(1): 133-139.

Lee TS (1985) Economic Insect Fauna of China, 30. Hymenoptera: Vespoidea. Science Press, Beijing, 153 pp.

Lopes RB, Noll FB, Stange LA (2017) Zethus (Zethus) wileyi (Hymenoptera, Vespidae, Eumeninae), a new species with its own species-group. Zootaxa 4231(1): 137-144. https://doi.org/10.11646/zootaxa.4231.1.11

Lopes RB, Kumagai AF, Stange LA, Hermes MG (2015) Cladistic analysis and systematic revision of the Zethus smithii (de Saussure) species-group sensu Bohart \& Stange (Hymenoptera: Vespidae: Eumeninae). Invertebrate Systematics 29: 421-443. https://doi.org/10.1071/IS15005

Hallam A (1994) An Outline of Phanerozoic Biogeography. Oxford University Press, Oxford.

Hermes MG, Melo GAR, Carpenter JM (2014) The higher-level phylogenetic relationships of the Eumeninae (Insecta, Hymenoptera, Vespidae), with emphasis on Eumenes sensu lato. Cladistics 30: 453-484. https://doi.org/10.1111/cla.12059

Hoffmann RS (2001) The southern boundary of the Palaearctic realm in China and adjacent countries. Acta Zoologica Sinica 47: 121-131.

Nguyen LTP, Carpenter JM (2016) Taxonomic review of the genus Zethus Fabricius (Hymenoptera: Vespidae: Eumeninae) from Vietnam with descriptions of four new species. Entomological Science 20: 24-32. https://doi.org/10.1111/ens.12218

Nguyen LTP, Xu ZF (2017) First record of the genus Zethus Fabricius, 1804 (Hymenoptera: Vespidae, Eumeninae) from China with description of a new species. Zootaxa 4272(4): 596-600. https://doi.org/10.11646/zootaxa.4272.4.10

Nidup T, Gyeltshen T, Kumar PG, Klein W, Dorji P (2016) New records of petiolate potter wasps (Hymenoptera: Vespidae: Eumeninae) from Bhutan. Journal of Threatened Taxa 8(12): 9467-9472. https://doi.org/10.11609/jott.2774.8.12.9467-9472 
Nugroho H, Kojima J, Carpenter JM (2012) Checklist of Vespid species (Insecta: Hymenoptera: Vespidae) occurring in Indonesian Archipelago. Treubia 38: 71-186.

Selis M (2017) Revision of the Zethus luzonensis species-group (Hymenoptera: Vespidae: Eumeninae), with description of a new species. Zootaxa 4232(3): 444-450. https://doi.org/10.11646/ zootaxa.4232.3.13

Tan JL, Carpenter JM, van Achterberg C (2018) An illustrated key to the genera of Eumeninae (Hymenoptera: Vespidae) from China, with a checklist of species. ZooKeys. [submitted]

Tan JL, He JH, Chen XX (2010) The Genus Minanga Cameron (Hymenoptera: Braconidae) in China, with description of a new subgenus and species. Annuals of the Entomological Society of America 103(3): 360-365. https://doi.org/10.1603/AN10001

Yeh WC, Lu SS (2017) New record of the genus Zethus Fabricius from Taiwan, with the description of $Z$. taiwanus sp. nov. and a key to the species of trimaculatus-group (Hymenoptera: Vespidae: Eumeninae). Zootaxa 4324(3): 529-540. https://doi.org/10.11646/zootaxa.4324.3.7

Zhou X, Chen B, Li, TJ (2011) The taxonomic research progress of Eumeninae (Hymenoptera: Vespidae). Journal of Chongqing Normal University (Natural Science) 28(6): 22-29. 